\title{
Teaching LOAC Vocabulary in a Military Classroom
}

\section{Nauczanie słuchaczy wojskowych słownictwa związanego z prawem konfliktów zbrojnych}

\author{
Sylwia Filipczuk-Rosińska \\ STUDIUMJ ĘZYKÓW OBCYCH, WYŻSZA SZKOŁA OFICERSKA SIŁ PO- \\ WIETRZNYCH, \\ UL. DYWIZJ ONU 303 NR 35, 08 - 521DĘBLIN \\ s.filipczuk@wsosp.pl
}

\begin{abstract}
This article is to present teaching methods adopted to develop lessons aimed at teaching vocabulary connected with LOAC (Law of Armed Conflict) to military personnel. Topics taken into consideration include: conduct of hostilities, prisoners of war (POW) and special signs. The presented exercises have been based on authentic materials such as: the Hague Convention, Geneva Conventions with additional protocols and rules of engagement cards. Additionally, the skills of speaking, reading and writing will be integrated. The exercises have already been conducted with professional soldiers as well as cadets at the Polish Air Force Academy in Dęblin.
\end{abstract}

"The LOAC arises from a desire among civilized nations to prevent unnecessary suffering and destruction while not impeding the effective waging of war. A part of public international law, LOAC regulates the conduct of armed hostilities. It also aims to protect civilians, prisoners of war, the wounded, sick, and shipwrecked. LOAC applies to international armed conflicts and in the conduct of military operations and related activities in armed conflict, however such conflicts are characterized".

Rod Powers, US military expert 


\section{Introduction}

The following paper presents a sample lesson aimed at teaching the Law of Armed Conflict ${ }^{1}$ vocabulary connected with conduct of hostilities, special signs and prisoners of war. It was conducted with fourth year cadets whose major is aircraft pilotage at the Faculty of Aeronautics and Aerospace of the Polish Air Force Academy in Dęblin in the academic year 2014/ 2015.

Additionally, teaching methods and approaches, which governed the development of the exercises will be discussed. Bearing in mind that the paper is not a comprehensive study, only a number of interrelated exercises have been selected. Their key function is to integrate the receptive skill of reading with the productive ones of speaking and writing by providing learners with topic vocabulary input.

\section{Idea and rationale}

The signing of the act, which made Poland a member of NATO on $18^{\text {th }}$ February 1999 by President Aleksander Kwaśniewski marked the beginning of radical changes for the Polish armed forces. Considerably increased presence in peacekeeping missions and war theatres outside the mother country resulted in a wide variety of reforms in a number of fields including English language teaching. Namely, NATO Standardization agreement STANAG 6001, which specifies English proficiency requirements on five levels ${ }^{2}$ ranging from no proficiency level 0 to expert level 5 of highly articulate native was implemented. Furthermore, in accordance with the Defence Planning Questionnaire 2006 (DPQ 2006) NATO language objective $\mathrm{G} 0356$ was enforced. It determines the language skills of military personnel ready for deployment and their improvement preferably to SLP3 3-3-33 for officers stipulated by STANAG 6001(Klich 2008).

In order to facilitate the achievement of language proficiency objectives, the Minister of National Defense issued a regulation no. 242/MON on 10th September 2002 and thus established the full-time Central Examination Board for Foreign Languages of the Ministry of National Defense based in Łódź. Furthermore, in order to ensure increasing each soldier's SLP, the Ministry of National Defence issued a regulation no. 403/MON on $5^{\text {th }}$ October 2006 (Dz. Urz. MON Nr 19, poz. 249). Namely, its second point obliges commanders of the armed forces, supervisors and commandants of higher military education institutions to encourage their person-

\footnotetext{
1Abbreviated to LOAC.

2 The following levels are distinguished:

Level 0 - No proficiency

Level 1 - Survival

Level 2 - Functional

Level 3 - Professional

Level 4 - Expert

Level 5 - highly-articulate native

http://www.natobilc.org/stanag/index-eng.asp, [date of access: 07 May 2015].

3 The abbreviation SLP stands for Standardized Language Profile - a term which indicates a soldier's knowledge of English on each particular level as regards the four skills of: listening, speaking, reading and writing.

4 Abbreviated to CEBFL.
} 
nel to participate in foreign language courses with a view to upgrading their language skills.

In consequence of such increased requirements in language proficiency, there has been a noticeable shift from teaching general English to teaching English for Special Purposes. Hence, the Polish Air Force Academy has developed syllabuses for aviation, logistics, tactics and the Law of Armed Conflict. Such a specialized modification was possible due to the fact that the general teaching strategy outlined by the Military Education Department in the Ministry of National Defence allows for a considerable degree of flexibility in the selection and development of teaching material and methods ${ }^{5}$.

\section{Key principles and theoretical background}

With a view to encouraging adult learners' self-direction, motivation, experience and practical application of knowledge, the teacher also adopted an "andragogical" approach (Knowles 1980).

All the exercises have been developed in accordance with the principles of the highly motivating Communicative Language Teaching Approach, which presupposes the integration of skills and use of authentic materials (Richards 2006: 3). Additionally, they are consistent with the task-based learning since

"the military culture is mission centered, where action is based on specific goals. Military student success is the academic classroom thus is enhanced by providing a structured format, clear and specific goals, with class activities mapped to those goals". (Smucny, Stover 2013: 8).

The teacher's assumption has also been to maximize the use of L2 $2^{6}$ in the classroom. Hence, the explanation of key LOAC concepts has been provided also in L2 not learners' L1.

Another key principle is the integration of skills. Therefore, all the exercises integrate the receptive skills of reading with the productive skill of speaking and writing. They are performed in groups, pairs or individually. Consequently, they not only foster learner autonomy but also encourage "cooperative learning", which is the incorporation of students working in groups to accomplish the same goal (Gillies 2007).

Furthermore, they are based either on authentic materials or present a level of authenticity due to restrictions of confidentiality imposed in view of the issue of national security. These materials include provisions of legal documents such as Geneva Conventions I-IV, the Hague Convention or customary international law as well as Rules of Engagement cards de-

5 Ramowy Program Nauczania J ęzyka Angielskiego w Siłach Zbrojnych RP Edycja III, Ministerstwo Obrony Narodowej Departament Nauki i Szkolnictwa Wojskowego, Warszawa (2009: 37).

$6 \mathrm{~L} 1$ is the learners' native language, whereas L2 refers to the language they are learning. 
signed by the general command of the armed forces to be used during joint military exercises by allied NATO countries. Additionally, they are complemented with visual materials such as photographs and maps created in cooperation with military personnel from the Faculty of Aeronautics and Aerospace at the Polish Air Force Academy and soldiers employed in the Dęblin Army Unit, who returned from deployment in Iraq or Afghanistan.

\section{Scenario}

With a view to providing learners' with a meaningful context for the use of LOAC vocabulary, the teacher creates a case study of an imaginary country complemented with a map and detailed factual conflict timeline. Such a scenario constitutes a peculiar framework for the whole lesson and subsequently developed exercises.

Simultaneously, it encompasses a wide range of issues subject to analysis based either on real or probable events (http:// web.stanford.edu). Real past or current conflicts are deliberately avoided because of the learners' apparent familiarity with them. This might lead them to activating their background knowledge or conducting research for readymade solutions in available bibliography, which would stifle critical and creative thinking.

\section{ZALANDIA}

an independent state since 1996 after the split of United Zaal Union into 3 republics: Zalandia, Katudu (N) and Salas (S);

a history of ethnic conflict: in the West: ethnic minority Katudians uprooted from Katudu in 1996, settle in W Zalandia. Their major city is Kathudu. Zalandia's government creates a province there with a special governor.

\section{CONFLICT TIMELINE}

1. 1996-1999 peaceful coexistence.

2. 20 May 1999 parliamentary elections and outbreak of disturbance. Riots erupt after Katudians' charismatic leader Jacob Kahala is shot during a rally. Police manages to maintain order without the intervention of the armed forces.

3. 21 May 1999 Katudians gain no seats, they suspect that results of the elections were falsified by Zalandia's government.

4. June 2000 Zalandia's government passes Law of Pure Race, which discriminates Katudians and limits their civil rights.

5. July 2001 Katudians form the Katudia Liberation Forces. They conduct a number of attacks, suicide bombings, take hostages. Police cannot contain the unrest. Emergency legislation is enacted. Armed forces assist the police.

6. August 2000 Regular fighting takes place in W Zalandia. Katudians overthrow the local authorities and proclaim the Katudian Republic with Kathudu as its capital.Zalandia launches an offensive. 
Figure 1. The imaginary country of Zalandia.

\subsection{Map}

This activity focuses on practicing speaking skills in a group. Learners are given a map of an imaginary area on which hostilities are conducted. They are tasked with identifying terrain features, types of military formations and special LOAC signs. They are also required to explain how these factors might affect the progress of hostilities or strategic decisions. Then, they listen to a briefing prepared by the teacher, mark enemy positions and movement on the map. They prepare a battle scenario and present it to the class. A class discussion of the proposed solutions follows.

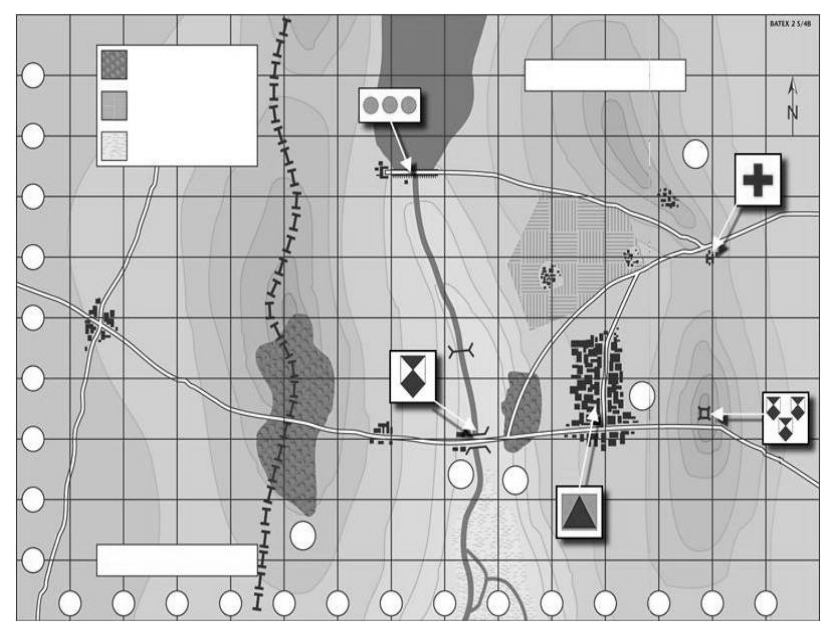

Picture 1. The battle area of Kahun.

\begin{tabular}{|l|l|}
\hline \multicolumn{2}{|l|}{ LOAC special signs and symbols } \\
\hline & $\begin{array}{l}\text { Medical services - civilian and military. } \\
\text { The Red Cross and Red Crescent. }\end{array}$ \\
\hline $\begin{array}{l}\text { Works and installations containing } \\
\text { dangerous forces - dams, dikes and nuclear } \\
\text { electrical generating station. }\end{array}$ \\
\hline $\begin{array}{l}\text { Cultural property - museums, statues, } \\
\text { temples, churches. }\end{array}$ \\
\hline $\begin{array}{l}\text { Civil defence - personnel and objects of civil } \\
\text { defense organizations. }\end{array}$ \\
\hline $\begin{array}{l}\text { White flag - used to designate unarmed } \\
\text { parliamentaries asking for truce, ceasefire or } \\
\text { willing to surrender. }\end{array}$ \\
\hline
\end{tabular}


Figure 2. Properly identified LOAC signs by learners.

The fact that the activity combines visual material with a short listening responds to the needs both of visual and auditory learners. The idea presents some authenticity since it bears resemblance to map reading tasks in real military conditions.

\subsection{Report}

This activity related to previous speaking exercises aims at practising writing skills. It accords with the written section of the examination format for STANAG 6001 level 2 created by the CEBFL. The objective of this exercise is also to practise not only LOAC vocabulary but also grammar, especially narrative tenses and passive voice. It is performed in the classroom or may be assigned as homework. The word limit is 200-250 words, whereas the time limit set in the classroom is one and a half hour. The activity is performed individually.

I Your special operations team conducted an attack on Katudia Liberation Forces HQ. Write a report to your commander about the operation. Include the following information:

$\ddot{y}$ forces:

1st Special commando unit, overwatch unit, anti armour suppression, tank-heavy hostile forces, 300 fighters armed with mortars, small calibre rifles;

$\ddot{y}$ casualties:

10 commandoes killed by IEDs, 3 suffered multiple gunshot wounds, CASEVAC;

ÿ civilians:

used as human shields by guerillas (what action you took, why: refer to LOAC);

$\ddot{y} \quad$ the battle area problems antitank ditch, Medieval church, nuclear power station (what action you took, why: refer to LOAC);

$\ddot{y}$ legitimate military objectives: which destroyed?;

ÿ 10 POWs taken:

will be sent to detention camp;

$\ddot{y}$ recommendations for the assistance for non-combatants.

Figure 3. The battle of Kahun - report.

Apart from developing a detailed instruction, the teacher provides prompts that cadets are obliged to use. Thus, it is an instance of guided practice. The prompts consist of factual information, LOAC vocabulary and military acronyms so characteristic of NATO speak - "the jargon of those who work for or collaborate with NATO, has its specific terminology 
and it also attributes specific meanings to general terms (...)" (Scharfhausen 2013).

In the sample report below, the acronyms stand for:

$\ddot{y} \quad$ IED = improvised explosive device

$\ddot{y} \quad$ CASEVAC $=$ casualty evacuation

$\ddot{y} \quad \mathrm{POW}=$ prisoner of war

$\ddot{\mathrm{y}} \mathrm{HQ}=$ headquarters

Moreover, the instruction includes a legal complication so that cadets are required to refer to the LOAC legal framework and consequently propose a solution, which has to be justified by an appropriate LOAC provision. The presented sample report has three such complications:

Example 1. Human shields

Cadets have to refer to Article 28 of the Fourth Geneva Convention Relative to the protection of Civilian Persons in Time of War and Article 51(3) of the 1977 Additional Protocol I. The former states that the "presence of a protected person may not be used to render certain points or areas immune from military operations." (Geneva Conventions 2010: 161). The latter mandates that civilians "shall enjoy the protection afforded" by the laws and customs of war "unless and for such time as they take a direct part in hostilities" (Protocols Additional 2010: 37).

Example 2. Medieval church

Cadets have to refer to the 1954 Hague Convention for the Protection of Cultural Property in the Event of Armed Conflict. It prohibits any act of hostility which may expose cultural property to destruction or damage in the event of armed conflict with the exception of "imperative military necessity" (Schindler and Toman 1988: 745-759).

Example 3. Nuclear power station

Cadets have to refer to Article 56 of the 1977 Additional Protocol I which states that "1. Works and installations containing dangerous forces, namely dams, dykes and nuclear electrical generating stations, shall not be made the object of attack, even where these objects are military objectives, if such attack may cause the release of dangerous forces and consequent severe losses among the civilian population. Other military objectives located at or in the vicinity of these works or installations shall not be made the object of attack if such attack may cause the release of dangerous forces from the works or installations and consequent severe losses among the civilian population" (Additional Protocol 2010: 40). It also stipulates conditions during which the protection 
ceases that also have to be taken into consideration by cadets while choosing the proper solution.

\subsection{Briefing}

The following exercise is an extension of an oral examination format for STANAG 6001 level 3 developed by the CEBFL. It aims at practicing the productive skill of speaking combined with the stimulation of cadets' creative and critical thinking capacities.

The teacher develops an instruction for a short five-minute monologue - the so-called briefing on a given issue connected with LOAC. The instruction includes two or three alternative solutions. The cadet's task is to individually prepare a speech within the allocated fifteen minutes. It involves presenting the issue, choosing one solution and justifying the choice by using LOAC vocabulary and quoting appropriate regulations.

\section{BRIEFING 5}

Your unit has apprehended a dangerous Al-Ka'ida terrorist. You have been tasked with transporting him for questioning to a CIA base situated 200 $\mathrm{km}$ away. Give a briefing on ways of transporting the terrorist safely, consider the advantages and disadvantages of the following options:

$\ddot{y}$ by land - minimally secured convoy at daytime;

$\ddot{y}$ by land + air support - one chopper, at night;

$\ddot{y}$ by air - chopper at night.

\section{POINTS TO CONSIDER}

1. by land = requires reconnaissance, cooperation with locals, ambush can take place

2. by land = trucks can break down, rocky terrain

3. by land $=$ need for a local guide

4. cost of solutions

5. air support $=$ bigger possibility of detection than discreet land transport

6. speed of transport

7. chopper $=$ dependent on weather conditions

8. night $=$ limited visibility of the unknown terrain

\section{USEFUL LANGUAGE}

1. to involve an increased possibility of ambush

2. to conduct prior accurate reconnaissance

3. availability of a chopper

4. favourable weather conditions

5. high visibility

6. to rely on landmarks

7. to fall prey to hostile locals 
Figure 4. Briefing concerning the apprehended terrorist (Filipczuk 2013: 139)

In addition to the instruction itself, the teacher offers two kinds of support. The first one is "points to consider" or more precisely sample arguments to which a cadet may refer. It has been provided at the learners' special request to guide them through the activity.The second kind called "useful language" is a list of collocations provided to activate cadets' LOAC and military vocabulary. The inclusion of such a list is consistent with basic premises of the Lexical Approach, according to which teaching should focus on chunks of language and routines not isolated lexemes so that communication can be enhanced (Lewis 1993).

\subsection{Trial}

This exercise is developed to improve speaking skills. The objective is to practise LOAC vocabulary by conducting a simulation of a trial with reference to the LOAC legal framework.

The simulation is performed in the classroom, yet it might be preceded by research of key legal concepts and preparation at home. The teacher prepares a case description including factual information concerning the defendant such as: age, background, nationality, engagement in the conduct of hostilities and type of committed crime.

\section{SERINA KALU}

$\ddot{y} \quad 19$ years old, Zalandia's citizen, daugther of a Katudian general;

$\ddot{y} \quad$ fled after her mother was killed by Zalandia's soldiers in an attack on her hometown, lived in a refugee camp in Salas;

$\ddot{y}$ returned to Zalandia, joined Katudia Liberation Forces, messenger;

$\ddot{y}$ tried to free her father, attacked the prison armed with rifle, arrested after shooting three armed guards. During the attack put on Katudia Liberation Forces' badge.

Figure 5. Sample trial case description

Having familiarized himself with the case description, each cadet is to choose one role card from a number of cards designed by the teacher. Those can be either basic and include only the name of a role or advanced with detailed factual information connected with a given testimony. Due to insufficient number of role cards, those not involved in the trial act as audience or journalists. In addition, a simulation of a press conference might be organized as a follow-up activity during which they will participate actively by asking questions.

1. Judge

2. Member of Grand J ury 
Sylwia Filipczuk-Rosińska: Teaching LOAC Vocabulary in a Military

Classroom

3. Serina Kalu

4. Member of Katudia Liberation Forces

5. Commander of Zalandia's troops

6. Passer-by

7. Serina's friend (also eye-witness)

Figure 6. Sample trial role cards

Taking into consideration information provided in the sample case description, cadets have to determine Serina Kalu's status. More specifically, by analyzing Article 43 (2) and 44 (3) of the 1977 Additional Protocol I they have to decide whether she is a combatant or non-combatant. If they pronounce her a non-combatant, then she has to be tried as a common criminal. In case of choosing the second option, she might be granted Prisoner of War status and thus entitled to special protection in accordance with Part II of the Third Geneva Convention Relative to the Treatment of Prisoners of War of 12th August 1949.

Having participated in Serina Kalu's trial and played their respective roles, cadets reached a verdict that the defendant was a combatant since she:

$\ddot{y} \quad$ was armed which was visible during the attack, which accords with Article 44 (3a) of the 1977 Additional Protocol I: "carries his arms openly during military engagement" (Protocols Additional 2010: 33).

ÿ was wearing a Katudia Liberation Forces' Badge, which accords with Article 44 (3b) of the 1977 Additional Protocol I: "during such time as he is visible to the adversary while he is engaged in a military deployment preceding the launching of an attack in which he is to participate" (ibid.).

Accordingly, she was granted a POW status and sent to a POW camp.

The most substantial benefit of this type of activity is that "students can become fully immersed within real decision-making processes, allowing the content of the course to become more relevant as the applicability of certain ideas and concepts become apparent" (Clayton and Gizelis 2005: 5). Thus, their critical thinking concerning legal concepts is enhanced.

\section{Concluding remarks}

To sum up, teaching LOAC vocabulary in a military classroom requires developing specific methods adjusted to military learners' professional needs and their occupational context. Firstly, activities should be based on authentic materials and introduce a relevant context for the specialized vocabulary input to be used. Secondly, activities ought to integrate productive and receptive skills, with an emphasis placed on speaking. Thirdly, learners ought to process the language input by conducting their own research while performing an analysis of legal provisions. Such 
principles are bound to significantly contribute to fostering learners' autonomy and developing their communicative competence. Hence, they will be more effective while performing their tasks during joint military exercises, on deployment or work within allied NATO command structure. 
Sylwia Filipczuk-Rosińska: Teaching LOAC Vocabulary in a Military

Classroom

\section{Bibliography}

Clayton G., Gizelis, T.-I. 2005. Learning through Simulation or Simulated Learning? An Investigation into the Effectiveness of Simulations as a Teaching Tool in Higher Education. http:// bisa.ac.uk/ files/ Permanent\%20Files/ClaytonGizelisBISAPAPER.pdf. [date of access: 10 May 2015].

Convention for the Protection of Cultural Property in the Event of Armed Conflict, signed at The Hague, 14 May 1954. 1988. reprinted in Dietrich Schindler and Jiri Toman (Eds.), The laws of armed conflicts: A collection of conventions, resolutions and other documents, $3^{\text {rd }}$ ed., Martinus Nijhoff/ Henry Dunant Institute. Geneva: Dordrecht.

Decyzja nr 403/ MON ministra obrony narodowej z dnia 5 października 2006 r. w sprawie kształcenia i egzaminowania ze znajomości języków obcych w resorcie obrony narodowej (Dz. Urz. MON Nr 19, poz. 249). Dziennik Urzędowy Ministra Obrony Narodowej Nr 19. Warszawa: dnia 31 października 2006.

Filipczuk, S. 2013. Developing speaking skills for advanced learners. Dęblin: WSOSP.

Gillies, R. M. 2007. Cooperative learning: Integrating theory and practice. Thousand Oaks, CA: Sage Publications.

Klich, Bogdan. 2008. Odpowiedź ministra obrony narodowej na interpelację $\mathrm{nr}$ $4416 \mathrm{w}$ sprawie podniesienia poziomu znajomości języka angielskiego przez cały stan osobowy Sił Wysokiej Gotowości Zdolnych do Przerzutu.

http://orka2.sejm.gov.pl/IZ6.nsf/main/389283BC [date of access: 12 May 2015].

Knowles, M. 1980. The Modern Practice of Adult Education: From Pedagogy to Andragogy. $2^{\text {nd }}$ ed. New York: Cambridge Books.

Lewis, M. 1993. The Lexical Approach: The State of ELT and a Way Forward. Hove, UK: Language Teaching Publications.

NATO Standardization Agreement STANAG 6001 NTG (EDITION 4) LANGUAGE PROFICIENCY LEVELS. 2010.

http:// www.natobilc.org/stanag/index-eng.asp, [date of access: 12 May 2015].

Protocols Additional to the Geneva Conventions of 12 August 1949. 2010. Geneva: International Committee of the Red Cross.

Powers, R. Law of Armed Conflict (LOAC). The Rules of War. http://usmilitary.about.com/cs/wars/a/loac.htm [date of access: 10 May 2015].

Ramowy Program Nauczania Języka Angielskiego w Sitach Zbrojnych RP Edycja III. 2009. Warszawa: Ministerstwo Obrony Narodowej Departament Nauki i Szkolnictwa Wojskowego.

Richards, J. C. 2006. Communicative Language Teaching Today. Cambridge: Cambridge University Press.

Scharfhausen, C. 2013. What is NATO Speak - The Spanish Perspective [PowerPoint presentation]. http:// www.natobilc.org/conference/2013/tbilisi-eng.asp [date of access: 25J uly 2015].

Smucny, D., Stover, M. 2013. Enhancing Teaching and Learning for Active-Duty Military Students. American Sociological Association Vol. 41, no. 3 (March/April), http:// www.asanet.org/ footnotes/marchapril13/military_0313. html [date of access: 2 J une 2015]. 
Teaching with Case Studies, Speaking of Teaching. 1994. Stanford University Newsletter on Teaching Vol. 5 No. 2 (Winter), http:// web.stanford.edu/ dept/ CTL/ Newsletter/ case studies.pdf [date of access: 10 May 2015].

The Geneva Conventions of $\overline{12}$ August 1949. 2010. Geneva: International Committee of the Red Cross. 